\title{
Construction of a single-copy integration vector and its use to study gene expression in Bacillus licheniformis
}

\author{
Lam-Son Phan Tran, Lóránd Szabó, László Orosz, Tibor Sík \\ and András Holczinger \\ Author for correspondence: Lam-Son Phan Tran. Tel: +3628410 200. Fax: +3628410804. \\ e-mail:tran@spike.fa.gau.hu
}

Department of

Biotechnology and

Molecular Genetics,

University of Agricultural

Sciences, Gödölló H-2103,

Hungary

\begin{abstract}
A versatile system consisting of an integrational vector and a bacitracin (Bt)producing $\beta$-galactosidase ( $\beta$-Gal)-negative (Lac') Bacillus licheniformis TLH strain was constructed to quantify promoter activity and to study gene regulation in a single-copy set-up. The vector PTLH utilizes the promoterless Escherichia coli lacZ gene derived from PQF52 and contains the PBR322 origin of replication and a kanamycin-resistance gene for selection in both $B$. licheniformis and $E$. coli. The vector also contains an inner part of the first gene of the Bt synthetase (bts) operon which enables its integration into the bts of $B$. licheniformis by Campbell-type recombination. This recombination event can be easily tested on a Micrococcus flavus lawn where loss of Bt production, i.e. no clearing zone on the lawn, is indicative of the proper integration. The Lac' B. licheniformis TLH strain was developed by elimination of the natural $\beta$-Gal activity of B. licheniformis strain ATCC 10716 UM12 using NTG mutagenesis.
\end{abstract}

Keywords: NTG mutagenesis, Campbell-type recombination, bacitracin synthetase, lacZ fusions, gene expression

\section{INTRODUCTION}

Bacillus licheniformis is used for the industrial production of the peptide antibiotic bacitracin $(\mathrm{Bt}), \alpha-$ amylase, $\beta$-lactamase, alkaline protease and alkaline phosphatase (Kleinkauf \& von Döhren, 1987; Harwood, 1992). In the framework of a strain improvement and genetic manipulation programme, the construction of a system to study gene expression and to analyse regulatory elements in $B$. licheniformis is indispensable.

Prokaryotic gene regulation is frequently studied using operon fusions carried on plasmids (for a review see Slauch \& Silhavy, 1991). Some of these, with the Escherichia coli lacZ gene as an indicator, have found widespread application in selecting or screening for transcriptional control signals and in studying regulation of various promoters. There are more advantages to using the lac $Z$ gene than other reporter genes: its product, $\beta$-galactosidase ( $\beta$-Gal), can be easily and sensitively measured by an assay for $\beta$-Gal activity

Abbreviations: $\mathrm{Bt}$, bacitracin; $\beta$-Gal, $\beta$-galactosidase; MCS, multi-cloning site. reported by Miller (1972), and there are various indicators that can be incorporated into plates to generate a colour change (e.g. X-Gal). In addition, the fluorogenic substrate MUG (4-methylumbelliferyl- $\beta$-D-galactopyranoside) is inexpensive and gives a product that can be visualized by UV light and is an exceedingly sensitive indicator (Errington, 1990). The use of antibioticresistance reporter genes is less versatile because of the expense and limited sensitivity of the available assay systems (Farinha \& Kropinski, 1990).

In Bacillus subtilis, a number of integrational vectors have been created which allow the construction of fusions with the lac $Z$ gene at either the transcriptional or translational level. The advantage of using integrational vectors is that obtaining the fusions does not necessarily result in gene disruption, and thus the pattern of regulation of essential genes can be monitored (Perego, 1993). Additionally, using integrational vectors, transcriptional and translational fusions can be analysed in single copy integrated via a Campbell-type mechanism into the wild-type locus of the cloned insert, or in single copy integrated into a heterologous, defined locus (Lewandoski \& Smith, 1988; Perego, 1993). The latter is thought to be more advantageous because: (i) the study 
of the transcriptional potential of a specific DNA fragment is accomplished in a transcriptionally neutral region of the chromosome, therefore the sequence at the normal chromosomal location of the gene used to create the fusion remains intact; (ii) deletion analysis to study the role of segments surrounding the promoter in gene regulation can be easily carried out; and (iii) lacZ fusions constructed of genes from organisms completely dissimilar to B. subtilis can be integrated. As a consequence, this approach, employing the amyE locus as the integration site, is frequently used in $B$. subtilis (Shimotsu \& Henner, 1986; Lewandoski \& Smith, 1988; Perego, 1993; Axel et al., 1996).

With full knowledge of the above advantages, the need to analyse the expression of regulated genes in $B$. licheniformis has motivated the development of a system which allows us to study gene expression and gene regulation in a heterologous, defined locus. To achieve this approach, we took advantage of the B. licheniformis ATCC 10716 UM12 strain, whose Bt production can be used for the easy testing of integrational events at the $\mathrm{Bt}$ synthetase (bts) locus. If the vector carrying an internal homologous fragment integrates into the bts operon by a Campbell-type mechanism, due to gene disruption, there will be no zone of clearing on the indicator lawn of Micrococcus flavus, which is sensitive to Bt. Furthermore, the rationale for the selection of the $B$. licheniformis ATCC 10716 UM12 strain is that it can be transformed with high efficiency by various methods (McCuen \& Thorne, 1971; Prágai et al., 1994). Thus the method that was based on the application of two + oripUB110 sequences in the same orientation on the parental plasmid, and used for integration of DNA sequences in the chromosome of poorly transformable bacilli (Tangney et al., 1995), is avoidable.

The use of the lac $Z$ gene as a reporter gene in $B$. licheniformis, however, incurs a major problem: all $B$. licheniformis strains, including $B$. licheniformis ATCC 10716 UM12, have natural $\beta$-Gal activity. Hence, to be able to study gene expression in a single-copy integrational state in B. licheniformis ATCC 10716 UM12 based on lacZ complementation, the elimination of its natural $\beta$-Gal activity is necessary.

In this article, we report the construction of a versatile system for studying gene expression in single copy integrated via a Campbell-type mechanism into the heterologous bts locus consisting of a promoter-probe pTLH vector and a $\mathrm{Lac}^{-}$mutant derivative of $B$. licheniformis ATCC 10716 UM12 isolated by NTG mutagenesis.

\section{METHODS}

Bacterial strains, bacteriophage, plasmids and media. $B$. licheniformis ATCC $10716 \mathrm{UM} 12$ is a $\mathrm{Lac}^{+}$, Bt-producing strain which is cured of phage LP52 (Thorne \& Kowalski, 1976). Its derivative, B. licheniformis TLH, is $\mathrm{Lac}^{-}$and was acquired by NTG mutagenesis. M. flavus ATCC 10240 (OKI) is a sensitive indicator strain for $\mathrm{Bt}$ and was used to detect $\mathrm{Bt}$ production by $B$. licheniformis strains. E. coli $\mathrm{DH} 5 \alpha$
$\left[\mathrm{F}^{-} /\right.$endA1 $h s d R 17\left(\mathrm{r}_{\mathrm{k}}^{-} \mathrm{m}_{\mathrm{k}}^{+}\right)$supE44 thi-1 recA1 $\operatorname{gyr} A\left(\mathrm{Nal}^{\mathrm{r}}\right)$ relA1 $\Delta$ (lacIZYA-argF)U169 deoR ( $\phi 80 \mathrm{~d}$ lac $\Delta[$ lacZ]M15)] was used for cloning experiments. B. licheniformis ATCC 9800 (OKI) and virulent bacteriophage BL11, which infects most $B$. licheniformis strains (Holczinger, 1986), were sources of various promoters. Plasmids used and constructed in this work are shown in Table 1. Strains were grown in YTA medium (Sík et al., 1980). If necessary, YTA medium was supplemented with ampicillin $\left(100 \mu \mathrm{g} \mathrm{ml}^{-1}\right)$, kanamycin $(10 \mu \mathrm{g}$ $\left.\mathrm{ml}^{-1}\right)$ and X-Gal $\left(40 \mu \mathrm{g} \mathrm{ml}^{-1}\right.$ for E. coli and $80 \mu \mathrm{g} \mathrm{ml}^{-1}$ for $B$. licheniformis). For the transformation of $B$. licheniformis protoplasts, media were used as described previously by Prágai et al. (1994b).

DNA techniques. Total DNA was extracted from $B$. licheniformis by the method of Bron (1990). Preparation of plasmid and phage DNA, restriction endonuclease digestion, filling-in of cohesive ends, ligation, agarose gel electrophoresis and transformation of $E$. coli competent cells were applied as described by Sambrook et al. (1989). NTG mutagenesis was carried out according to Cutting \& Vander Horn (1990). The PEG-induced transformation procedure for B. licheniformis protoplasts was reported previously by Prágai et al. (1994). Southern hybridization was performed using the DIG DNA Labeling and Detection kit as described in the protocol (Boehringer Mannheim). Enzymes were purchased from MBI Fermentas and Pharmacia Biotech and used according to the manufacturers' instructions.

Assay for Bt production. The colonies were picked onto plates containing $M$. flavus, which is sensitive to $\mathrm{Bt}$. The $\mathrm{Bt}^{+}$and $\mathrm{Bt}^{-}$ phenotypes can be distinguished easily. Around colonies of $\mathrm{Bt}^{+}$ strains, a zone of clearing indicates growth inhibition of $M$. flavus, which becomes visible after incubation for $24 \mathrm{~h}$ at $37^{\circ} \mathrm{C}$. In the case of the $\mathrm{Bt}^{-}$phenotype, this effect cannot be seen.

Assay of $\beta$-Gal activity. Overnight cultures were diluted 100 fold in fresh YTA medium and cultivated to the early exponential growth phase $\left(\mathrm{OD}_{600}=0.24\right.$; UV1101 Biotech Photometer). The cultures were again diluted 100 -fold and grown at $37^{\circ} \mathrm{C}$ with intensive agitation (in an incubated shaker at 250 r.p.m.). Samples were collected at hourly intervals from the third hour for $\mathrm{OD}_{600}$ readings and $\beta$-Gal activity determinations. The $\beta$-Gal assay and the calculation of activities (expressed as units per $\mathrm{OD}_{600}$ ) were carried out as described by Miller (1972).

\section{RESULTS AND DISCUSSION}

\section{Isolation of the Lac $^{-}$B. licheniformis TLH strain}

After mutagenesis of strain B. licheniformis ATCC 10716 UM12 with NTG, the mutagenized stock was screened for mutants unable to express $\beta$-Gal. From approximately 5000 surviving colonies, one white colony, called B. licheniformis TLH ( $\mathrm{Lac}^{-}$mutant), was found on X-Gal plates. The $\beta$-Gal activity of this mutant was measured in extracts from cells grown overnight, and found to be approximately five times lower than that of the wild-type strain. To determine the reversion frequency, the $B$. licheniformis TLH mutant was grown for 20 generations in YTA broth. The cells were then washed with sterile distilled water and the dilutions were plated on YTA agar containing X-Gal. No $\mathrm{Lac}^{+}$ revertants were observed among $9 \cdot 2 \times 10^{8}$ c.f.u. $\mathrm{ml}^{-1}$, therefore the reversion rate was less than $10^{-9}$ per 
Table 1. Plasmids

\begin{tabular}{|c|c|c|}
\hline Plasmid & Relevant characteristics & Reference \\
\hline pQF52 & $6.8 \mathrm{~kb}$, carrying promoterless $l a c Z$ gene, $\mathrm{Ap}^{\mathrm{r}}$ & McLean et al. (1997) \\
\hline pBR322 & $4.4 \mathrm{~kb}, \mathrm{Ap}^{\mathrm{r}} \mathrm{Tc}^{\mathrm{r}}$ & Bolivar et al. (1977) \\
\hline pBE1 & $\begin{array}{l}12 \cdot 1 \mathrm{~kb} \text {, carrying the left arm of } \mathrm{Tn} 917 P F 1 \text { and the } \\
\text { flanking part of the bts region }\left(b t s A^{\prime}\right), \mathrm{Ap}^{\mathrm{r}} \mathrm{Km}^{\mathrm{r}} \mathrm{Cm}^{\mathrm{r}}\end{array}$ & Prágai (1994) \\
\hline pGP100 & $9 \cdot 1 \mathrm{~kb}$, carrying bacteriophage SPO2 promoter, $\mathrm{Km}^{\mathrm{r}} \mathrm{Tc}^{\mathrm{r}}$ & Meima et al. (1996) \\
\hline pKSA11 & $\begin{array}{l}6.2 \mathrm{~kb} \text {, carrying the promoter of the } B . \text { subtilis } 168 \\
\text { pyrimidine biosynthetic (pyr) gene cluster, } \mathrm{Ap}^{\mathrm{r}}\end{array}$ & Prágai et al. (1997) \\
\hline pBRQF & $\begin{array}{l}5.6 \mathrm{~kb} \text {; pBR322 replicon with the lacZ reporter gene } \\
\text { carried on the } 3.8 \mathrm{~kb} \mathrm{~N} d e \mathrm{I}-S c a \mathrm{I} \text { fragment from pQF52, } \\
\mathrm{Km}^{\mathrm{r}}\end{array}$ & This study \\
\hline pTLH & $\begin{array}{l}8.6 \mathrm{~kb} ; \mathrm{pBRQF} \text { with } 3 \mathrm{~kb} E c o \mathrm{RI}-\mathrm{Bam} \mathrm{HI} \text { fragment } \\
\text { carrying an internal part }\left({ }^{\prime} b t s A^{\prime}\right) \text { of the bts region and } \\
\text { the left end of Tn917PF1 from } \mathrm{pBE} 1, \mathrm{Km}^{\mathrm{r}}\end{array}$ & This study \\
\hline pTLHspo2 & $\begin{array}{l}8.9 \mathrm{~kb} ; 0.3 \mathrm{~kb} \text { EcoRI fragment from pGP100 carrying } \\
\mathrm{P}_{\mathrm{SPO} 2} \text { promoter in pTLH, transcriptional } \mathrm{P}_{\mathrm{SPO} 2}-l a c Z \\
\text { fusion, } \mathrm{Km}^{\mathrm{r}}\end{array}$ & This study \\
\hline pTLHpyr & $\begin{array}{l}9.4 \mathrm{~kb} ; 0.8 \mathrm{~kb} \text { Xhol-Hincli fragment from pKSA11 } \\
\text { carrying } \mathrm{P}_{\text {pyr }} \text { promoter in pTLH, transcriptional } \\
\mathrm{P}_{\text {pyr }}-\text { lac } Z \text { fusion, } \mathrm{Km}^{\mathrm{r}}\end{array}$ & This study \\
\hline pTLHbli & $\begin{array}{l}9.6 \mathrm{~kb} \text {, carrying a } 1 \mathrm{~kb} \text { Sau3A fragment with promoter } \\
\text { activity from ATCC } 9800, \mathrm{Km}^{\mathrm{r}}\end{array}$ & This study \\
\hline pTLH11 & $\begin{array}{l}9.8 \mathrm{~kb} \text {, carrying a } 1.2 \mathrm{~kb} \text { Sau } 3 \mathrm{~A} \text { fragment with promoter } \\
\text { activity from bacteriophage } \mathrm{BL} 11, \mathrm{Km}^{\mathrm{r}}\end{array}$ & This study \\
\hline
\end{tabular}

generation. The NTG mutagenesis did not affect Bt production of the B. licheniformis TLH strain. Hence, $b t s$ can be used as the integration site and then the production of $\mathrm{Bt}$ is used for testing integrational events.

\section{Construction of the pTLH vector}

To construct versatile integrational vector pTLH for studying gene expression in $B$. licheniformis TLH, we took advantage of the promoterless lac $Z$ gene derived from pQF52, which is a promoter-probe vector and capable of replicating in a wide range of Gram-negative bacteria (McLean et al., 1997), and of the multi-cloning site (MCS) placed upstream of the lac $Z$ gene. In the latter construct, the first 15 bases of the lac $Z$ gene were replaced with the Shine-Dalgarno sequence and the first 12 bases of the $E$. coli lipoprotein $(l p p)$ gene (Kalnins et al., 1983; Nakamura \& Inouye, 1982; Ruther et al., 1981). This region also contains translational stop codons in all three reading frames located between the MCS and the translation initiation codon of the indicator gene. The above topology prevents initiation of translation from other start sites into the indicator gene which may have unwanted effects on its expression. The hybrid $\beta$-Gal is enzymically indistinguishable from the native protein, which is one amino acid longer.

The lac $Z$ gene from pQF52 was excised as a $3.8 \mathrm{~kb}$ NdeI-ScaI fragment and ligated to pBR322 cut with the same enzymes, creating a $5.6 \mathrm{~kb} \mathrm{pBRQF}$, which is smaller than pQF52 $(6.8 \mathrm{~kb})$, because the ori ${ }_{1600}$ (Olsen et al., 1982) was deleted. As a next step, the $3 \mathrm{~kb}$ fragment containing the $\mathrm{Km}^{\mathrm{r}}$ gene and the flanking internal part ('bts $A^{\prime}$ ) of the bts operon in pBE1 (Prágai, 1994) was purified upon digestion with EcoRI and $B a m H I$. The ends of this fragment were filled in, and the resulting fragment was ligated to $\mathrm{pBRQF}$ digested with ScaI, creating the final product, pTLH, which is $8.6 \mathrm{~kb}$ in size (Fig. 1). The two trpA terminators placed upstream of the MCS were sufficient to prevent readthrough transcription from promoters located in the pQF52 region of the plasmid (Farinha \& Kropinski, 1990).

\section{Testing of the pTLH-B. licheniformis TLH system}

To demonstrate that the pTLH-B. licheniformis TLH system can be used to investigate gene expression in a single copy, the indicator lacZ gene was fused with the $\mathrm{P}_{\mathrm{SPO} 2}$ promoter (a constitutive promoter derived from the $B$. subtilis bacteriophage SPO2) and with the $\mathrm{P}_{\mathrm{pyr}}$ promoter of the B. subtilis 168 pyrimidine biosynthetic (pyr) gene cluster. To construct the $\mathrm{P}_{\mathrm{SPO} 2}$-lacZ transcriptional fusion, the $0.3 \mathrm{~kb}$ EcoRI fragment carrying $\mathrm{P}_{\mathrm{SPO} 2}$ was deleted from plasmid pGP100 (Meima et al., 1996), the ends of the fragment were made blunt and inserted into pTLH digested with StuI, creating the pTLHspo2 plasmid. To construct the $P_{\text {pyr }}-$ lacZ transcriptional fusion, the $\mathrm{P}_{\text {pyr }}$ promoter from pKSA11 (Prágai et al., 1997) was transferred as a $0.8 \mathrm{~kb} \mathrm{HincII-}$ Xhol fragment to pTLH cut with StuI and XhoI, creating the pTLHpyr plasmid. E. coli cells were transformed, and lacZ fusions were detected on X-Gal 


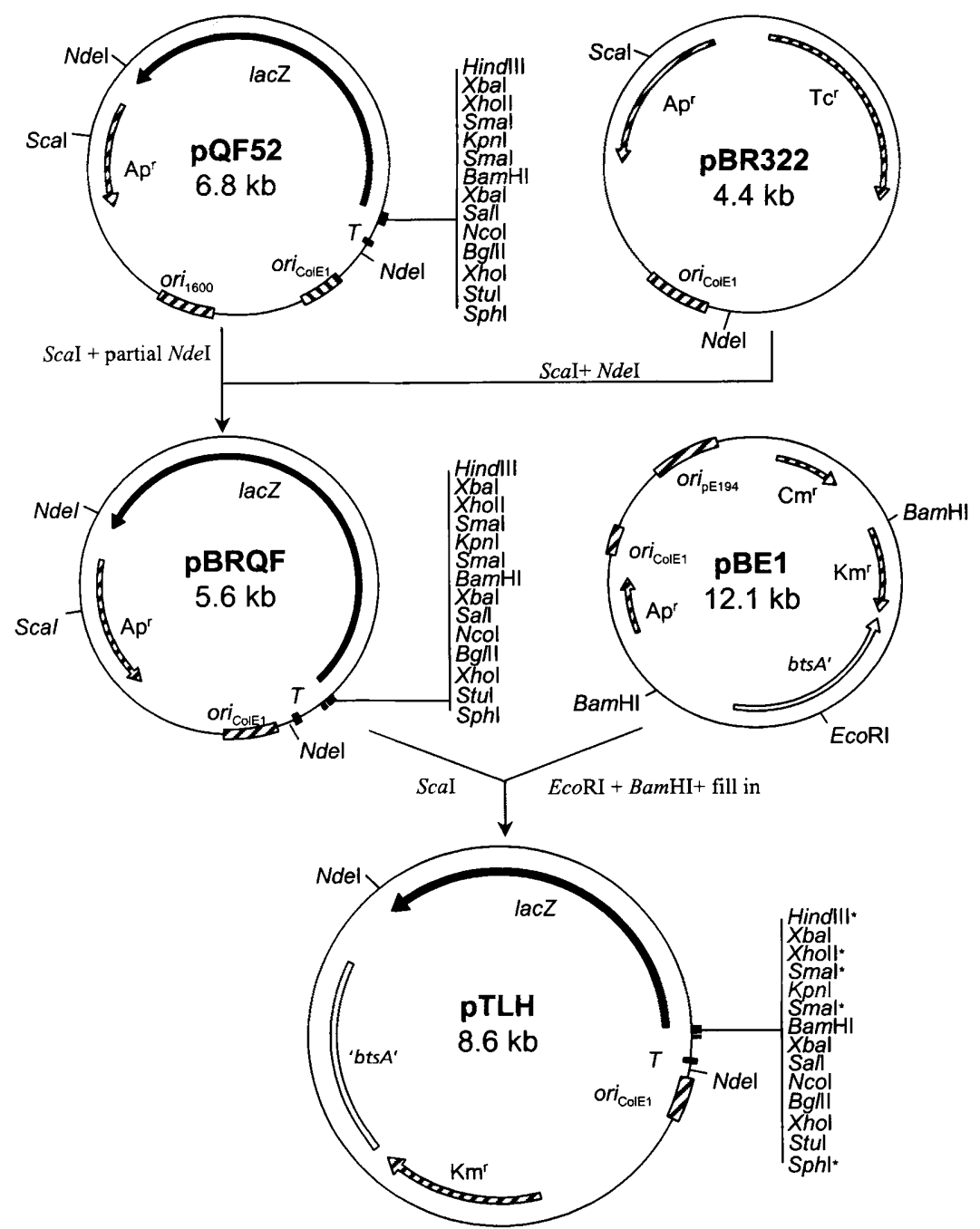

Fig. 1. Schematic presentation of the construction of PTLH. The open arrow represents part (bts $A^{\prime}$ ) of the bts operon and the open box represents the internal part ('bts $A$ '). The lac $Z$ gene is marked by a black arrow. The $\mathrm{Ap}^{r}, \mathrm{Km}^{r}, \mathrm{Tc}^{r}$ and $\mathrm{Cm}^{r}$ markers are shown as hatched arrows and the replication origins are shown as hatched boxes. The small black box represents the two trpA terminators ( $T)$. Non-unique restriction sites in the MCS are indicated by asterisks.

indicator plates, where promoter-positive clones manifested themselves as blue colonies. Subsequently, the two transcriptional fusions were integrated via a Campbell-type integration into the bts operon of $B$. licheniformis TLH using kanamycin for selection in protoplast transformation of this strain. The promoterless insertions served as controls. Insertion by a Campbell-type recombination at the bts was verified by the $\mathrm{Bt}^{-}$phenotype of the cells, which could be identified on an indicator lawn of M. flavus.

The efficiency of transformations was $1-2 \times 10^{2} \mathrm{Km}^{\mathrm{r}}$ and $\beta$-Gal-producing transformants per $\mu \mathrm{g}$ plasmid DNA, which is approximately $10^{4}$ times lower than that $\left(1.1 \times 10^{6}\right)$ with plasmids carrying Gram-positive replication origins (Prágai et al., 1994). Accordingly, the frequency of integration was approximately $10^{-4}$ per $\mu \mathrm{g}$ plasmid DNA. Transformation of E. coli with total DNA extracted from $\mathrm{Km}^{\mathrm{r}} \mathrm{Bt}^{-}$integrants resulted in no transformants, indicating the stable integration of the pTLH, pTLHspo2 and pTLHpyr plasmids in the bts operon of the B. licheniformis integrants and also the lack of autonomously replicating plasmids. The presence of a single copy of pTLH, pTLHspo2 and pTLHpyr in the first bts gene of $B$. licheniformis integrants was confirmed by Southern hybridization analysis (data not shown).

One integrant was chosen from each plasmid type and subsequently assayed quantitatively for the activity of the $l a c Z$ reporter gene product. The results, presented in Fig. 2, showed that in the absence of a promoter, enzymic activities were barely detectable, contrasted with the presence of the promoters, especially in the case of the constitutive $\mathrm{P}_{\mathrm{SPO} 2}$ promoter, where enzymic activities increased significantly (Fig. 2).

The test concluded above showed that this system is suitable for studying gene expression in $B$. licheniformis strain TLH. The advantage of the $b t$ s operon as the integration site is that it provides an easily detectable phenotype for integration events. To the best of our knowledge, the system described above is the first versatile system for analysing regulatory elements in single-copy set-up in $B$. licheniformis.

In addition, pTLH is a useful tool for selection of promoters from various sources. To demonstrate this practical use, fragments with promoter activity from $B$. 


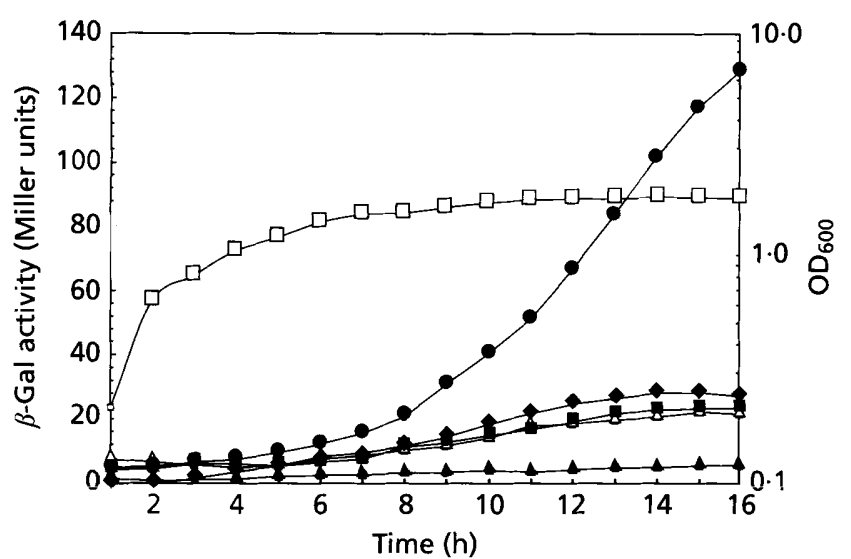

Fig. 2. Testing of the $\mathrm{PTLH}-B$. licheniformis TLH system. $B$. licheniformis strain TLH carrying a promoterless $\mathrm{pTLH}$ as a control ( $\mathbf{\Lambda})$, a $\mathrm{P}_{\mathrm{SPO} 2}-$ lac $Z$ transcriptional fusion (0), a $\mathrm{P}_{\mathrm{pyr}}-$ lac $Z$ transcriptional fusion ( $\square$ ), a $\mathrm{P}_{\mathrm{bli}}-\mathrm{lacZ}$ transcriptional fusion ( $\bullet$ ) and a $P_{11}-l a c Z$ transcriptional fusion $(\triangle)$ was grown in YTA medium. Samples were collected at hourly intervals for $\mathrm{OD}_{600}$ readings ( $\square$, growth curve, log scale) and for assaying $\beta$-Gal activities. Data are expressed as means of three independent experiments.

licheniformis ATCC 9800 and bacteriophage BL11 were cloned by linearizing pTLH with BamHI and ligating Sau3A fragments from B. licheniformis ATCC 9800 and phage BL11 to the linearized vector. Insertion of the Sau 3 A fragments carrying promoters can be selected by plating transformants of $E$. coli on media supplemented with X-Gal. Promoter-positive clones manifested themselves as blue colonies. One randomly selected clone from each type, called pTLHbli and pTLH11, carrying $\mathrm{P}_{\mathrm{bli}}-$-lac $\mathrm{Z}$ and $\mathrm{P}_{11}-$ lac $Z$ transcriptional fusions, respectively, was integrated via a Campbell-type mechanism into the bts operon. The integrants were checked for $\mathrm{Km}^{\mathrm{r}}$ and $\mathrm{Bt}^{-}$phenotype. Southern hybridization was used to confirm the presence of a single copy of pTLHbli and pTLH11 in the first bts gene of $B$. licheniformis integrants. The $\beta$-Gal activity of these integrants was also investigated and shown in Fig. 2. The $\mathrm{Km}^{\mathrm{r}} \mathrm{Bt}^{-}$ integrants carrying various transcriptional fusions at the $b t s$ locus, including $\mathrm{P}_{\mathrm{bli}}-l a c Z$, are very stable and can be maintained without kanamycin.

The promoter-probe pTLH plasmid can also be used to screen for regulatory mutants. If the transcriptional fusion is negatively regulated, expression in the wildtype background will be low, resulting in a low $\beta$-Gal activity. In contrast, inactivation of the repressor gene will lead to increased $\beta$-Gal activity. If the transcriptional fusion is positively regulated, expression will be high and inactivation of the gene encoding the activator will result in low or even no $\beta$-Gal activity.

We have shown in this paper that the $\mathrm{Lac}^{-} B$. licheniformis TLH mutant, a derivative of $B$. licheniformis ATCC 10716 UM12 isolated by NTG mutagenesis, is extremely stable. The NTG mutagenesis did not affect the ability of $B$. licheniformis strain TLH to produce $\mathrm{Bt}$. Thus, bts can be used as the integration site and the production of $\mathrm{Bt}$ is then applied for testing integrational events. We constructed the promoterprobe pTLH vector carrying a promoterless lac $Z$ reporter gene, the pBR322 replicon and a $\mathrm{Km}^{\mathrm{r}}$ gene for selection in both B. licheniformis and E. coli. This vector also contains an internal part of the first gene of the $b t s$ operon, allowing insertion of transcriptional fusions into the B. licheniformis TLH bts by a Campbell-type recombination. Successful integration can be visualized on a $M$. flavus lawn and directly selected for with kanamycin. Using different promoters fused to the lacZ reporter gene to test the system consisting of the pTLH vector and the $B$. licheniformis TLH strain, we showed that the system is suitable for studying gene expression. pTLH can also be used as a promoter-probe vector.

\section{ACKNOWLEDGEMENTS}

We are grateful to Professor T. Imanaka, Professor A. M. Kropinski and Dr R. Meima for the generous gifts of plasmids and strains. Special thanks to T. Ponyi for critical reading of the manuscript. This work was supported by grants from CEF Higher Education Development Fund (870/2 1993-1994), from the Hungarian Ministry of Education (MKM 842), from the Hungarian Academy of Sciences (MTA/AKT-F442/95), from the National Scientific Research Fund (OTKA, grant no. T-016092 and F-015898) and from the PhD Programs of the University of Agricultural Sciences, Gödöllo”.

\section{REFERENCES}

Axel, M., Hayward, R. \& Schumann, W. (1996). Integrative vectors for constructing single-copy transcriptional fusions between Bacillus subtilis promoters and various reporter genes encoding heat-stable enzymes. Gene 182, 33-36.

Bolivar, F., Rodriguez, R. L., Greene, P. J., Betlach, M. C. Heynecker, H. L., Boyer, H. W., Crosa, J. H. \& Falkow, S. (1977). Construction and characterization of new cloning vehicles. II. A multipurpose cloning system. Gene 2, 95 .

Bron, S. (1990). Plasmids. In Molecular Biological Methods for Bacillus, pp. 75-174. Edited by C. R. Harwood \& S. M. Cutting. Chichester: Wiley.

Cutting, S. M. \& Vander Horn, P. B. (1990). Genetic analysis. In Molecular Biological Methods for Bacillus, pp. 27-74. Edited by C. R. Harwood \& S. M. Cutting. Chichester: Wiley.

Errington, J. (1990). Gene cloning techniques. In Molecular Biological Methods for Bacillus, pp. 175-220. Edited by C. R. Harwood \& S. M. Cutting. Chichester: Wiley.

Farinha, M. A. \& Kropinski, A. M. (1990). Construction of broadhost-range plasmid vectors for easy visible selection and analysis of promoters. J Bacteriol 172, 3496-3499.

Harwood, C. R. (1992). Bacillus subtilis and its relatives: molecular biological and industrial workhorses. Trends Biotechnol 10, 247-256.

Holczinger, A. (1986). Improvement of bacitracin production and bacteriophages of Bacillus licheniformis. $\mathrm{PhD}$ thesis, Budapest Technical University.

Kalnins, A., Otto, K., Ruther, U. \& Muller-Hill, B. (1983). Sequence of the lacZ gene of Escherichia coli. EMBO J 2, 593-597.

Kleinkauf, H. \& von Döhren, H. (1987). Biosynthesis of peptide antibiotics. Annu Rev Microbiol 41, 259-289. 
Lewandoski, M. \& Smith, I. (1988). Use of a versatile lacZ vector to analyze the upstream region of the Bacillus subtilis spoOF gene. Plasmid 20, 148-154.

McCuen, R. W. \& Thorne, C. B. (1971). Genetic mapping of genes concerned with glutamyl polypeptide production by Bacillus licheniformis and a study of their relationship to the development of competence for transformation. J Bacteriol 107, 636-645.

McLean, B. W., Wiseman, S. L. \& Kropinski, A. M. (1997). Functional analysis of $\sigma^{70}$ consensus promoters in Pseudomonas aeruginosa and Escherichia coli. Can J Microbiol 43, 981-985.

Meima, R., Venema, G. \& Bron, S. (1996). A positive selection vector for the analysis of structural plasmid instability in Bacillus subtilis. Plasmid 35, 14-30.

Miller, J.H. (1972). Experiments in Molecular Genetics, pp. 352-355. Cold Spring Harbor, NY: Cold Spring Harbor Laboratory.

Nakamura, K. \& Inouye, M. (1982). Construction of versatile expression cloning vehicles using the lipoprotein gene of Escherichia coli. EMBO J 1, 771-775.

Olsen, R. H., DeBusscher, G. \& McCrombie, W. R. (1982). Development of broad-host-range vectors and gene banks: self-cloning of the Pseudomonas aeruginosa $\mathrm{PAO}$ chromosome. J Bacteriol 150, 60-69.

Perego, M. (1993). Integrational vectors for genetic manipulation in Bacillus subtilis. In Bacillus subtilis and Other Gram-Positive Bacteria, pp. 615-624. Edited by A. L. Sonenshein, J. A. Hoch \& R. Losick. Washington, DC: American Society for Microbiology.

Prágai, Z. (1994). Transposon mutagenesis and protoplast transformation of Bacillus licheniformis. PhD thesis, Hungarian Academy of Sciences.
Prágai, Z., Holczinger, A. \& Sík, T. (1994). Transformation of Bacillus licheniformis protoplasts by plasmid DNA. Microbiology 140, 305-310.

Prágai, Z., Tjalsma, H., Bolhuis, A., van Dijl, J. M., Venema, G. \& Bron, S. (1997). The signal peptidase II (lsp) gene of Bacillus subtilis. Microbiology 143, 1327-1333.

Ruther, U., Koenen, M., Otto, K. \& Muller-Hill, B. (1981). pUR222, a vector for cloning and rapid chemical sequencing of DNA. Nucleic Acids Res 9, 4087-4098.

Sambrook, J., Fritsch, E. F. \& Maniatis, T. (1989). Molecular Cloning: a Laboratory Manual, 2nd edn. Cold Spring Harbor, NY: Cold Spring Harbor Laboratory.

Shimotsu, H. \& Henner, D. J. (1986). Construction of a single-copy integration vector and its use in analysis of regulation of the trp operon of Bacillus subtilis. Gene 43, 85-94.

Sík, T., Horváth, J. \& Chatterjee, S. (1980). Generalized transduction in Rhizobium meliloti. Mol Gen Genet 178, 511-516.

Slauch, J. M. \& Silhavy, T. J. (1991). Genetic fusions as experimental tools. Methods Enzymol 204, 213-248.

Tangney, M., Jørgensen, P. L., Diderichsen, B. \& Jørgensen, S. T. (1995). A new method for integration and stable DNA amplification in poorly transformable bacilli. FEMS Microbiol Lett $125,107-144$.

Thorne, C. B. \& Kowalski, J. B. (1976). Temperate bacteriophages for Bacillus licheniformis. In Microbiology, pp. 303-314. Edited by D. Schlessinger. Washington, DC: American Society for Microbiology.

Received 2 April 1998; revised 10 June 1998; accepted 12 June 1998. 